\title{
Growth Illusion in The Indonesia Stock Exchange: Relationship Between Earnings Management and Firm Value
}

\author{
AGUS SATRYA WIBOWO* \\ Universitas Palangkaraya
}

\author{
FUAD \\ Universitas Diponegoro
}

\begin{abstract}
This research aimed to examine whether earnings management (EM) proxied with the practice of accrual management (AM) and real activity manipulations $(R M)$ is related to the increase of firm value $(F V)$ in the manufacturing industry in the IDX in the period 2010-2014. Subsequently, based on the normative and formal testing, the fixed effect model was selected as the appropriate model. The results of this empirical investigation indicate that an abnormal production cost (RMP) based RM practice tends to increase FV. Nevertheless, AM and abnormal discretionary expenses (RMD) based RM do not exhibit the same evidence. The results of the additional testing showed that the relationship between EM and FV differed when the firm was audited by an auditor affiliated with the big 4 auditors, when there was an institutional investor in the firm ownership and when IFRS was adopted. This research contributes to the literature on earnings management by suggesting that value creation drives the increase of FV by managers through the practices of RMPbased earnings management. The results indicate misinformation between the managers and the market, which makes FV growth become a mere illusion. Furthermore, the proposed model is expected contribute to researchers, regulators, investors, and analysts in evaluating the quality of accounting numbers and predicting the value relevance of earnings.
\end{abstract}

Keywords: Accrual Management, Real Activity Manipulations, Accounting Numbers, Overvaluation

Intisari: Penelitian ini bertujuan untuk menguji apakah manajemen laba (EM) yang diproksikan dengan praktik manajemen akrual (AM) dan manipulasi aktivitas riil $(R M)$ terkait dengan peningkatan nilai perusahaan $(F V)$ dalam industri manufaktur di BEI di periode 2010-2014. Selanjutnya, berdasarkan pengujian normatif dan formal, fixed effect model dipilih sebagai model yang paling sesuai. Hasil dari investigasi empiris menunjukkan bahwa praktik RM berbasis abnormal production cost (RMP) cenderung meningkatkan FV. Namun demikian, AM dan RM berbasis abnormal discretionary expenses (RMD) tidak menunjukkan bukti yang sama. Hasil dari pengujian tambahan menunjukkan bahwa hubungan antara EM dan FV berbeda ketika perusahaan diaudit oleh auditor yang berafiliasi dengan auditor big 4, ketika

*Corresponding author: satrya.upr@gmail.com 
adanya investor institusional di dalam kepemilikan perusahaan, dan ketika IFRS telah diadopsi. Penelitian ini berkontribusi pada literatur tentang manajemen laba dengan menunjukkan bahwa peningkatan FV didorong oleh penciptaan nilai melalui praktik manajemen laba berbasis RMP. Hasilnya menunjukkan mis-informasi antara manajer dan pasar menciptakan pertumbuhan FV hanya ilusi belaka. Selanjutnya, model yang diusulkan diharapkan dapat membantu peneliti, regulator, investor dan analis dalam mengevaluasi kualitas angka akuntansi dan memprediksi relevansi nilai atas laba perusahaan.

Kata kunci: Manajemen Akrual, Manipulasi Aktivitas Riil, Angka Akuntansi, Overvaluation

\section{Introduction}

Contracts are generally based on accounting numbers and unable to align the interests of different managers, and the drawing-up of the contracts causes the managers to be involved in opportunistic behaviors (Watts and Zimmerman, 1990). These opportunistic motivations of the managers are manifested through the earnings management based on bonuses received when the FV increases and even overvalued. Moreover, Healy (1985) presented empirical evidence that accrual management (AM) is related to managers' motivation based on bonus incentives. This evidence is supported by the findings of Badertscher (2011), showing that the powerful incentives for maintaining the overvalued equity value are used by managers to improve their prosperity through share options or bonuses relating to firm performance. This condition indicates a conflict of interest between managers and stakeholders (Jensen \& Meckling, 1976).

Increasing FV is reflected in an overvalued equity value, that is when a firm's share price is higher than the fundamental value (Jensen, 2005). Furthermore, Jensen (2005) showed that overvalue occurs when there are misinformation and manipulation contributed by investors, managers, analysts, securities, auditors, commercial banks and legal firms. This condition poses an extremely adverse consequence as the management tries to maintain this condition by creating values to deceive the market through growth illusion. Eventually, when the market detects the truth that the growth 
is none other than an illusion, the FV will drastically plunge due to the loss of market trust (Badertscher, 2011; Jensen, 2005; Marciukaityte \& Varma, 2008).

On the other hand, Barton \& Waymire (2004) found a relationship between earnings quality and overvalue that was proxied with the price to book ratio. They presented evidence that poor information of the fundamentals of a firm is related to overvalued FV. When earnings management can increase the earnings and earnings growth expectation, FV inflation may be resulted (Dechow, Hutton, \& Sloan, 2000). Similarly, earnings management may influence FV when there is information asymmetry between managers and investors (Chaney \& Lewis, 1995). Thus, by using the information asymmetry, the managers will potentially practice earnings management to increase FV.

Chaney \& Lewis (1995) found that earnings management practices influence FV (proxied with a present value of expected cash flow) when the purpose of the managers is to maximize value. Earnings management will result in biased accrual, which weakens the accrual quality (Doyle, Geand Mc Vay, 2007), indicating that the earnings quality is poor. Based on the investigation with a sample of 7,000 companies from 38 countries, Gaio \& Raposo (2011) showed that the earnings quality proxied with accrual quality has a positive relationship with FV proxied by Tobin's Q.

However, none of the previous studies has examined FV measured with a metric developed by Rhodes-Kropf et al. (2005) and related it with earnings management. This measure had a powerful estimation ability, i.e., explaining $80-94 \%$ variance of FV. Therefore, this research offered a tested and robust FV predictive ability. Furthermore, this research presented a sensitivity analysis when the model was influenced by differences in the conditions of auditing quality, ownership, and IFRS adoption.

This research aims to examine the relationship between earnings management and FV in the manufacturing sector of the Indonesia Stock Exchange. More specifically, this research investigates the effect of AM, RMP, and RMD on FV. The findings of this research show empirical evidence of the relationship between RMP and FV. However, the relationship between AM or RMD and FV was not identified. These 
results indicate that RMP practices can bring investor reactions, reflected in FV change/increase. Moreover, the investors did not respond positively to the AM or RMD practiced by the managers in the manufacturing sector in the Indonesia Stock Exchange.

This research is sensitive to the firm's environmental characteristic conditions. More specifically, this research presents empirical evidence that there were differences in the relationships between AM, RM, and FV, when the companies were audited by auditors affiliated with the big 4 auditors when there were institutional investors in the firm ownership and before and after the IFRS was adopted.

\section{Theoretical Framework and Hypothesis Development}

\subsection{Overvaluation of Equity Hypothesis}

The source of agency problem is the involvement of managers in the earnings management with the purpose of producing desired earnings performance in maintaining firm value as shown by overvalued share prices (Jensen, 2005). This is the underlying assumption of this research built upon the agency theory, that is the overvaluation of equity hypothesis, that earnings management leads to FV increase (Jensen, 2005). Badertscher (2011) proved that if FV is in an overvalue condition, managers are driven to maintain this condition by fulfilling market expectations and tend to be involved in earnings management.

Furthermore, earnings management is a way for creating values practiced by opportunistic managers to create an impression that the earnings performance is excellent (Badertscher, 2011; Jensen, 2005; Marciukaityte and Varma, 2008). Thus, earning management is a manifestation of value creation for attaining better FV condition, and it is triggered by the opportunistic behaviors of the managers upon the compensation to be given (e.g., bonuses or share options). This argument is supported by the hypothesis proposed by Jensen (2005) that managers tend to be involved in earnings management (AM and $\mathrm{RM}$ ) to meet unrealistic performance expectation, which is reflected in the share prices that are higher than the fundamental value (overvalue). 


\subsection{Hypothesis Development}

\subsubsection{Accrual Management (AM) and Firm Value $(F V)$}

$\mathrm{AM}$ is an approach to manipulate earnings by using available accruals. Zang (2012) stated that accrual-based earnings management (AM) is practiced by altering the accounting or estimation method used when presenting transactions in financial statements.

The adverse impact of AM practices was shown by Marquardt and Wiedman (2004), who found that opportunistic managers in AM practices can cause damages to value relevance of accounting information reflected in the increased share prices. This finding is consistent with the argument by Jensen (2005), who stated that AM practice is value creation for deceiving the market and giving a growth illusion to the market. This is in line with the findings of Teoh, Welch, \& Wong (1998), who showed that increased accruals are related to poor firm performance.

Furthermore, based on the Compustat and CRSP data in the sample period 19821994, Hunt, Moyer, Shevlin (2000) presented evidence that increased AM has a significant relationship with the market value of equity. A similar finding was demonstrated by Gaio and Raposo (2010), with a sample of 7,000 companies from 38 countries in 1990-2003, who presented evidence that there is a significant, positive relationship between earnings quality (proxied with accrual quality) and firm value. This expectation can be stated in the following hypothesis:

H1. Increased accrual management can encourage firm value $(F V)$ increase.

\subsubsection{Real Activity Manipulation (RM) and Firm Value (FV)}

Gunny (2010) explained that RM occurs when managers conduct an activity that can alter the timing or structurization of operation, investment and/or financing transaction to influence the output of the accounting system. Besides, Zang (2012) stated that RM is a measure aimed to modify earnings, with a consequence of less optimum business. Thus, RM practice is, in fact, a change of firm operational activity to obtain earnings. Roychowdhury (2006) stated that the RM method could be 
implemented through sales manipulation, overproduction, and discretionary payment delay.

Gunny (2010) proposed some reasons why firms prefer RM to AM. One of the reasons is that RM is under the control of the managers through the decision in the business operation, while accounting choice or AM is limited by auditor supervision Gunny (2010). Graham, Harvey, \& Rajgopal (2005) showed robust evidence that managers favor real economic measures to maintain earnings performance. Their research showed that as an effort to meet the earnings target, $80 \%$ of the survey respondents reduced and/or delay discretionary expenses of research \& development, advertising, and maintenance. Furthermore, more than half (55.3\%) of the respondents deferred the start of a new project to meet the earnings target in spite of the considerable consequences for the sacrificed value.

In line with those findings, Cohen \& Zarowin (2010) explained that earnings management using the RM method is more common than AM method. This is due to the tendency of AM to attract the attention of auditors or supervision of regulators more than real decisions. Similarly, Kothari, Mizik, \& Roychowdhury (2012) demonstrated that managers are more inclined to be involved in RM than AM during seasoned equity offering (SEO) although RM is deemed to be more costly in the long run. Additionally, they showed that RM practice encourages firm value increase (overvalue), but eventually adversely affects the market performance.

Efendi et al., (2007) proposed that companies involved in RM tend to have high firm value. This finding is consistent with Badertscher (2011), who found that managers practice AM in the early stage of overvaluation and shift to RM to maintain high firm value (overvalue). Thus, managers practice RM to increase the firm value. Based on those findings, the following hypotheses were formulated:

H2a.Increased abnormal production cost (RMP) based on real activity manipulation encourages firm value (FV) increase.

H2b.Increased abnormal discretionary expenses (RMD) based on real activity manipulation encourages firm value (FV) increase. 
Figure 1

Empirical Model

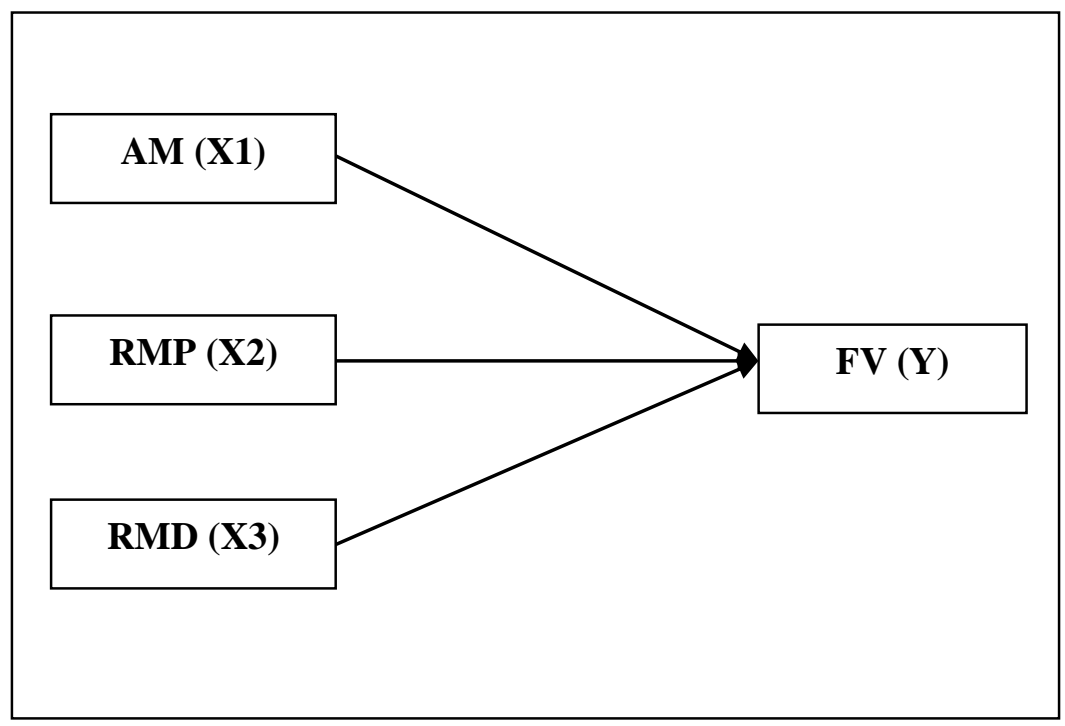

\section{Research Methods}

\subsection{Population and Sampling}

The population of this research consisted of 141 firms in the manufacturing sector listed on the Indonesia Stock Exchange (IDX) during the period 2010-2014 (see table 1). The selection of the manufacturing industry is of relevance to RPM measurements which require estimation of the cost of goods sold data. The sampling criterion was that the companies were in the manufacturing sector listed on the Indonesia Stock Exchange (IDX) in 2009-2014 due to lag-1 in the AM and RM formulae. Afterward, the sample was analyzed using panel data analysis as it can present more informative data, has high variability, has low colinearity between variables and has an adequate degree of freedom (Gujarati, 2004). After carrying out sampling based on balanced panel assumption, a sample of 104 companies per year with a period of 5 years was obtained. As many as 37 companies were excluded from the sample as their financial statement data were incomplete. 
Table 1

Sample Selection

\begin{tabular}{lc}
\hline Sample characteristics & Number of firms \\
\hline
\end{tabular}

\section{Panel A: Description}

$\begin{array}{ll}\text { Manufacture firms } & 141\end{array}$

Insufficient financial data

Final sample per year 104

Final sample in 2010-2014 520

\section{Panel B: Composition the final sample of manufacturing firms}

1 Cement 3

2 Ceramics, Glass, Porcelain 6

3 Metal and Allied Product 10

4 Chemicals 7

5 Plastics and Packaging 9

6 Animal Feed 3

7 Wood Industries 2

8 Pulp and Paper 4

9 Machinery and Heavy Equipment 0

10 Automotive and Components 12

11 Textile, Garment 13

12 Footwear 2

13 Cable 6

14 Electronics 0

15 Food and Beverages 10

16 Tobacco Manufactures 3

17 Pharmaceuticals 8

18 Cosmetics and Household 3

19 Housewares 3

Total the final sample per year 104

Final sample in 2010-2014 520 


\subsection{Operational Definitions and Variable Measurement}

\subsubsection{Firm Value $(F V)$}

Following the metric developed by Rhodes-Kropf et al., (2005), this research developed a firm value measure which was able to capture mis-valuation and growth opportunistic potential reflecting information asymmetry. This research used the same metric (Chi and Gupta, 2009; Efendi et al., 2007; Fu, Lin, and Officer, 2013; Lin, Chou, and Cheng, 2011; Siougle, 2007) and proved that this measure was able to detect misvaluation reflecting equity growth illusion.

In the first stage, Rhodes-Kropf et al. (2005) decomposed market to book value (M/B) into two components,

$M / B=M / V \times V / B$

(2)

where $V M /$ reflects mis-valuation, and $V / B$ indicates growth opportunistic.

In the second stage, equation (2) was decomposed into a logarithm form, and the lower-case letters in the following formula represent the logarithm values, $(m-b)=(m-v)+(v-b)$

where $m$ is the market value, $b$ is the book value, and $v$ is the fundamental value.

Then, in the third stage, equation (3) above was decomposed into three components for firm $i$ and year:

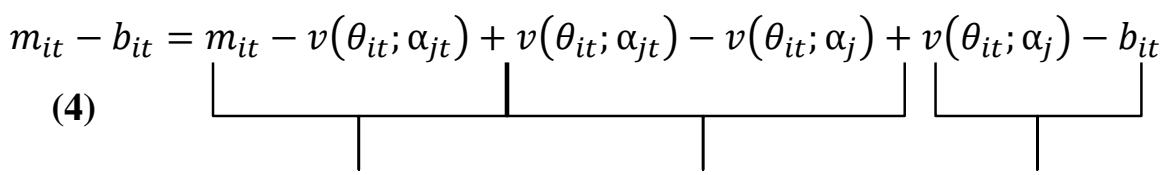

Firm-specific-error Industry-level error Long-run valuation

According to Rhodes-Kropf et al., (2005), in order that equation (4) above can be operated, $v\left(\theta_{i t} ; \alpha_{j t}\right)$ and $v\left(\theta_{i t} ; \alpha_{j}\right)$ should be estimated and decomposed into, 
$\mathrm{m}_{\mathrm{it}}=\alpha_{0 \mathrm{jt}}+\alpha_{1 \mathrm{jt}} \mathrm{b}_{\mathrm{it}}+\alpha_{2 \mathrm{jt}} \mathrm{ni}_{\mathrm{it}}^{+}+\alpha_{3 \mathrm{jt}} \mathrm{I}_{(<0)} \mathrm{ni}_{\mathrm{it}}^{+}+\alpha_{4 \mathrm{jt}} \mathrm{LEV}_{\mathrm{it}}+\varepsilon_{\mathrm{it}}$

Where $m_{i t}$ is the log value of market value, $b_{i t}$ is the log value of book value, $\mathrm{ni}_{\mathrm{it}}^{+}$is the log value of net income, $I_{(<0)}$ equals to 1 if the net income is negative and equals to 0 if the net income is positive and $\mathrm{LEV}_{\text {it }}$ is the leverage ratio.

Afterward, equation (5) was applied using cross-section regression to estimate the firm value of every firm per year. If the market price did not reflect the true value, $\mathrm{ln}$ would be positive during overvalue and negative during undervalue.

\subsubsection{Accrual Management (AM)}

This research followed the metric built by Dechow, Sloan, \& Sweeney (1995), i.e., Modified Jones Model (1991), which assumed that the change occurring in the current period is an object of earnings management,

$\frac{T A_{i t}}{A_{i t-1}}=\alpha_{1}\left(\frac{1}{A_{t-1}}\right)+\alpha_{2}\left(\Delta R_{t-1}\right)+\alpha_{3}\left(\frac{P P E_{t}}{A_{t-1}}\right)+\varepsilon_{t}$

(6)

Where $T A_{i t}$ is the total accrual of firm $\mathrm{i}$ in period $\mathrm{t}, A_{t-1}$ is the total asset in period $\mathrm{t}$, $\Delta R_{t-1}$ is net in the sales change in period $\mathrm{t}$, and PPEt is the property, plants, and equipment. Then, equation (6) was estimated with regression in a cross-sectional method to obtain the AM value of every firm every year. The residual value of this estimation captured the AM measure, which is the proxy of earnings management.

\subsubsection{Real Activity Manipulation (RM)}

The RM measurement followed the metric built by (Dechow, Kothari, \& Watts, 1998) and developed by Roychowdhury (2006), which was proxied with abnormal production cost (RMP) and abnormal discretionary expenses (RMD). Previous studies used the same metric and proved that this measure was able to capture RM with high accuracy (Braam, Nandy, Weitzel, \& Lodh, 2013; Zang, 2012).

This abnormal production cost was estimated with cross-section regression (Roychowdhury, 2006), 
$\frac{P R O D_{t}}{A_{t-1}}=\propto_{0}+\propto_{1}\left(\frac{1}{A_{t-1}}\right)+\propto_{2}\left(\frac{S_{t}}{A_{t-1}}\right)+\propto_{3}\left(\frac{\Delta S_{t}}{A_{t-1}}\right)+\propto_{4}\left(\frac{\Delta S_{t-1}}{A_{t-1}}\right)+\varepsilon_{t}$

(8)

where PRODt is the cost of goods sold (COGS) in year $t$ and the inventory change from $\mathrm{t}-1$ to $\mathrm{t}$; At-1 is the asset total in year $\mathrm{t}-1$; St is the net sales in year $\mathrm{t}$ and $\Delta \mathrm{Stis}$ the change of net sales from year t-1 to t. Abnormal production cost was measured using the residual estimation of that equation. The higher the residual, the higher the amount of oversupply and the bigger the earnings increase by reducing the COGS.

Then, the abnormal discretionary expenses were estimated with cross-section regression (Roychowdhury, 2006),

$\frac{D I S X_{t}}{A_{t-1}}=\propto_{0}+\propto_{1}\left(\frac{1}{A_{t-1}}\right)+\propto_{2}\left(\frac{S_{t-1}}{A_{t-1}}\right)+\varepsilon_{t}$

(7)

where DISXt is the discretionary expenses (i.e., the amount of R\&D, advertising and SG\&A expenses) in year t. At-1 is the asset total in year t-1. St is the net sales in year $\mathrm{t}-1$. Abnormal discretionary expenses were measured using the residual estimation value from the regression. High residual value (low) shows high abnormal discretionary expenses (low).

\subsubsection{Control Variable}

This research used some control variables to control some firm characteristics relating to the research model. Previous empirical evidence showed that SIZE has a positive relationship with $q$-ratio, which is the proxy of firm value(Ameer, 2012). Another finding showed a positive relationship between SIZE and Tobin's Q as a proxy for firm value (Davydov, Nikkinen, \& Vähämaa, 2014). Furthermore, ROA has a positive relationship with the proxy price to earnings ratio of high equity value, which is the reflection of firm value (Houmes, Foley, \& Cebula, 2013). Following Badertscher (2011), this study includes ROE as a control variable for controlling differences in firm performance. Thus, some control variables that potentially affect FV are included in this study. 


\subsection{Data Analysis Methods}

On a normative basis, Gujarati (2004) stated that when the sample size is small, i.e., fewer than 100 observations, the normality assumption plays a material role. However, if the size sample is relatively big, the normality assumption is negligible. Moreover, Gujarati (2004) stated that if the residual is distributed in an asymptotic manner rather than normally, OLS estimator is still normally distributed (unbiased) and the procedures of $t$-test and F-test are still applicable, and this will not apply in a limited or small sample. According to this assumption, this research did not employ the normality test as the sample size was reasonably big, i.e., 520 observations (more than 100 observations) and the OLS estimation remained unbiased.

Subsequently, classical assumption tests, namely autocorrelation estimated using Durbin Watson (DW) and multicollinearity test using a correlation coefficient, were carried out. However, heteroscedasticity test may be neglected as it is a specific problem in cross-section and time-series data (Gujarati, 2004). For this reason, this research did not conduct the heteroscedasticity test as it used panel data analysis.

In the next stage, the Common OLS, Fixed Effect, and Random Effect models were implemented for testing the model specification. The model in this research is as follows,

$$
F V_{i t}=\alpha+\beta_{1} A M_{i t}+\beta_{2} R M P_{i t}+\beta_{3} R M D_{i t}+\beta_{4} R O A+\beta_{5} R O E_{i t}+\beta_{6} S I Z E_{i t}+\varepsilon_{i t}
$$

where $F V_{i t}$ is overvalued metric-based firm value (Rhodes-Kropf et al., 2005), $R M P_{i t}$ is abnormal production cost-based real activity manipulation (Roychowdhury, 2006), $R M D_{i t}$ is abnormal discretionary expenses-based real activity manipulation (Roychowdhury, 2006), $R O A_{i t}$ is the return on asset ratio, $R O E_{i t}$ is the return on equity ratio, and $S I Z E_{i t}$ is the natural $\log$ of the total asset.

Furthermore, this research used a statistical instrument eviews 8 to analyze and test the model better and more accurately based on the Common OLS, Fixed Effect or Random Effect model. The best model was tested formally using Redundant Fixed Effect Test and Hausman Test. 
Common OLS estimation is an approach that neglects spatial and temporal dimensions. Gujarati (2004) showed that Common OLS assumes the intercept value and slope coefficients of all individuals as the same and assumes that Durbin-Watson value tends to be low or an indication of autocorrelation. This is contrary to the reality that every firm is unique and can be influenced by the temporal dimension and individuals. Therefore, Common OLS results can distort the correct or significant picture of the relationship between variables.

Fixed effect model (FEM) estimation can overcome the drawback of OLS model by considering the difference between companies (e.g., managerial styles, working cultures) and time (e.g., technological changes, changes in government regulations/policies). The individualistic characteristics of every firm can be accommodated by freeing the varied or constant intercept and slope coefficients in every firm (Gujarati, 2004).

Hereafter, this research took into account the condition without lag or lag-1 in the three models. This was aimed to anticipate the period of time in the market response to the impacts of AM and RM practices on the firm value. Besides, this testing could present useful evidence as both a leading indicator and lagging indicator.

\section{Results}

\subsection{Descriptive Statistics}

The descriptive statistics of the sample of 520 firms in the panel data regression are reported in table 2 . The mean (median) value of variable FV showed a positive mark, 0.944 (0.939), which indicated that most FVs were beyond the fundamental/true value (overvalue). In other words, this positive value suggested that the market did not reflect the true value on the firm value (Rhodes-Kropf et al., 2005). Also, an AM means (median) value of 0.029 (0.031) reflected that the managers tended to practice accrual management, but some firms did not practice AM, indicated by a minimum value of 1.208 . 
Table 2

Descriptive Statistics

\begin{tabular}{lccccc}
\hline \multicolumn{1}{c}{ Variables } & Mean & Minimum & Median & Maximum & Std. Dev \\
\hline FV & 0.944 & 0.838 & 0.939 & 1.166 & 0.042 \\
AM & 0.029 & -1.208 & 0.031 & 0.820 & 0.136 \\
RMD & $9.29 \mathrm{E}-18$ & -0.788 & 0.046 & 0.382 & 0.157 \\
RMP & $-9.56 \mathrm{E}-17$ & -0.673 & -0.052 & 1.455 & 0.234 \\
ROA & 0.065 & -0.755 & 0.047 & 0.669 & 0.122 \\
ROE & 0.103 & -7.684 & 0.107 & 3.246 & 0.573 \\
SIZE & 14.076 & 9.266 & 13.943 & 19.181 & 1.611 \\
\hline
\end{tabular}

An RMD means (median) value of 9.29E-18 (0.046) signified that on average, the RMD rate was minuscule, but some managers practiced RMD, proven by a maximum value of 0.382 . Another finding showed that a negative RMP means (media) value, 9.56E-17 (-0.052), indicated that on average, the RMP rate was still low. Nevertheless, a maximum value of 1.455 showed that some managers practiced RMP.

The mean (median) value of variable ROA was 0.065 (0.047), indicating that the companies included in the sample generally had a net income to total assets ratio of $6.5 \%$. In short, on average, the companies had positive earnings or a reasonable degree of profitability. On the other side, an ROE means (median) value of $0.103(0.107)$ proved that most of the earnings performance to equity was very good, i.e., $10.3 \%$. Lastly, the natural logarithm value in the mean (median) of the variable SIZE was 14.076 (13.943).

Table 3 showed the correlations of all variables. The highest correlation value was observed in the relationship between RMD and RMP, namely -0.784. This evidence reflected the interdependence in the managers' decisions between RMP and RMD practices. In other words, RMP and RMD were not executed simultaneously; this also indicated the presence of substitution. 
Table 3

Correlation Coefficient

\begin{tabular}{|c|c|c|c|c|c|c|c|}
\hline Variables & OV & $\mathrm{AM}$ & RMD & RMP & ROA & ROE & SIZE \\
\hline 1. $\mathrm{FV}$ & 1.000 & & & & & & \\
\hline 2. $\mathrm{AM}$ & -0.017 & 1.000 & & & & & \\
\hline 3. RMD & $-0.284 * * *$ & -0.026 & 1.000 & & & & \\
\hline 4. RMP & $0.367 * * *$ & -0.035 & $-0.784 * * *$ & 1.000 & & & \\
\hline 5. $\mathrm{ROA}$ & $0.254 * * *$ & $0.169 * * *$ & $-0.326 * * *$ & $0.567 * * *$ & 1.000 & & \\
\hline 6. ROE & $0.158 * * *$ & -0.019 & $-0.115 * * *$ & $0.218 * * *$ & $0.215^{* * *}$ & 1.000 & \\
\hline 7. SIZE & $0.181 * * *$ & -0.052 & 0.053 & 0.024 & $0.206^{* * * *}$ & $0.091 * *$ & 1.000 \\
\hline
\end{tabular}

\subsection{Appropriate Model Selection}

Table 4 of panel A showed that the probability F statistic was significant; thus hypothesis zero was rejected, and FEM was considered as better than Common OLS. Meanwhile, panel B showed that hypothesis zero was rejected. In conclusion, FEM was not appropriate, and FEM was used instead (Gujarati, 2004).

Consequently, if the chi-square value in the Hausman test is significant (prob 0.000), hypothesis zero is rejected and the FEM model is better than the REM model. Given this research results, further discussion is based on the FEM model.

\subsection{Hypothesis Testing}

Table 5 presents multiple regression analysis results from equation 1 tested using Common OLS, Fixed Effect (FEM) and Random Effect (REM) models. Regarding the selection of the appropriate model, further interpretation will be made using the FEM model.

FEM model (without lag) showed that the Durbin-Watson value was 1.984, which indicated that the model was only slightly affected by autocorrelation as the value approached 2. Meanwhile, in lag-1, there was no autocorrelation, which was shown by 
a Durbin-Watson value of 2.233. Furthermore, this research was free of the multicollinearity problem, which was reflected in a correlation value of below 0.8 .

Table 4

Formal Test

Panel A: Fixed Effect Model (FEM) vs. Common OLS

\section{Redundant Fixed Effect Test}

H0: FEM estimators are no better than common OLS

H1: FEM estimators better than common OLS

\begin{tabular}{cccc}
\hline Tested & & Prob & Conclusions \\
& Without lag & 0.000 & FEM \\
FV, AM, RMD, RMP, ROA, ROE, SIZE & Lag -1 & 0.000 & FEM
\end{tabular}

Panel B: Fixed Effect Model (FEM) vs. Random Effect Model (REM)

\section{Hausman Test}

H0: FEM estimators are no better than REM

H1: FEM estimators better than REM

\begin{tabular}{cccc} 
Tested & & Prob & Conclusions \\
& Without lag & 0.000 & FEM \\
FV, AM, RMD, RMP, ROA, ROE, SIZE & Lag -1 & 0.002 & FEM \\
\hline
\end{tabular}

Table 5

Regression Analysis

\begin{tabular}{|c|c|c|c|c|c|c|}
\hline \multirow{2}{*}{$\begin{array}{c}\text { Independent } \\
\text { Variables }\end{array}$} & \multicolumn{2}{|c|}{ Common OLS } & \multicolumn{2}{|c|}{ FEM } & \multicolumn{2}{|c|}{ REM } \\
\hline & Without lag & Lag -1 & Without lag & Lag -1 & Without lag & Lag -1 \\
\hline Constant & $0.881 * * *$ & $0.907 * * *$ & $1.132 * * *$ & $0.795^{* * *}$ & $0.856^{* * *}$ & $0.896 * * *$ \\
\hline $\mathrm{AM}$ & -0.000 & -0.021 & 0.005 & 0.006 & 0.004 & -0.019 \\
\hline RMP & $0.056 * * *$ & $0.043 * * *$ & $0.034 * * *$ & $0.020^{*}$ & $0.046 * * *$ & $0.032 * *$ \\
\hline RMD & -0.009 & -0.026 & 0.041 & 0.003 & -0.021 & -0.035 \\
\hline ROA & 0.006 & 0.023 & $-0.040 * *$ & -0.005 & -0.004 & 0.021 \\
\hline ROE & 0.005 & $0.005^{*}$ & -0.000 & 0.001 & 0.004 & $0.005^{*}$ \\
\hline $\begin{array}{l}\text { SIZE } \\
\end{array}$ & $0.004 * * *$ & $0.003 * *$ & $-0.013 *$ & 0.011 & $0.006 * * *$ & $0.003 * *$ \\
\hline $\operatorname{Adj}-R^{2}$ & 0.160 & 0.172 & 0.749 & 0.725 & 0.087 & 0.094 \\
\hline F-Statistic & $17.482 * * *$ & $15.451 * * *$ & $14.711 * * *$ & $10.810 * * *$ & $9.339 * * *$ & $8.226 * * *$ \\
\hline Aic & -3.620 & -3.711 & -4.651 & -4.605 & & \\
\hline DW & 1.199 & 1.277 & 1.984 & 2.233 & 1.434 & 1.822 \\
\hline
\end{tabular}


Hereafter, every model was tested with time period without lag and in lag-1 in the independent variables. It can be seen that the level of determination showed by Adj-R ${ }^{2}$ value for without lag (lag-1) was 0.749 (0.725) and it could be concluded that the independent variables could explain the dependent variable at $74.9 \%(72.5 \%)$ and the F-statistic was significant at $p$-value $<0.01$, while the remaining was explained by another variable outside this model.

Furthermore, AM and RMD coefficients were not significant, which showed that AM did not have any relationship with FV. Therefore, $\mathrm{H} 1$ and $\mathrm{H} 2 \mathrm{~b}$ were rejected. This evidence indicated that companies practicing AM would not improve their FVs. However, the findings showed empirical evidence that $\mathrm{H} 2 \mathrm{a}$ could not be rejected and showed that there was a significant, positive relationship between RMP and FV. These results were significant both in without lag with a coefficient of 0.034 ( $p$-value < $0.001)$ and lag-1 with a coefficient of 0.020 ( $p$-value $<0.10)$. These results indicated that the RMP variance could explain the FV variance.

Value creation through RMP could increase optimism and expectation of FV growth. This result is consistent with the findings of Barton and Simko, (2002), Chaney and Lewis, (1995) and Jensen, (2005), who stated that RM is related to FV that is greater than a fundamental value (overvalue). Additionally, these results supported Efendi et al., (2007) and Badertscher (2011), who proved that firms with RM indications are more likely to have high FV. Thus, it can be concluded that managers who practice RM will increase the FV.

The estimation in the control variable showed that ROA had a significant, negative relationship with FV in without lag condition, but insignificant in lag-1 condition. Furthermore, there was no significant relationship between ROE and FV, either in without lag or lag-1 condition. These findings served as evidence that ROE change does not encourage change in FV. Finally, variable SIZE had a significant, negative relationship with FV only in without lag condition, but insignificant in lag-1 condition. 


\subsection{Discussion}

The value creation mechanisms manifested through AM and RMD did not have any relationship with FV. The results of the research proved that only RMP has a significant relationship with FV. These findings indicated that RMP practice by increasing production excessively results in the decreased cost of goods sold and increased firm earnings. This will lead to an increase in the market expectation on the earnings performance reported, which is evident in the increased FV.

Nonetheless, the market responds to the earnings performance positively as it is not aware that the accounting numbers have been manipulated through RMP. The market's optimism about the earnings performance growth resulted can meet the market's expectation and cause increased FV, which, in fact, is none other than the growth illusion. Thus, the findings of this study indicate that managers tend to be involved in RMP (Cohen \& Zarowin, 2010; Kothari, Mizik, \& Roychowdhury, 2012; Efendi et al., 2007) to improve FV (Badertscher, 2011).

This evidence showed that the managers had successfully created value through RMP practice. This happened due to misinformation between the managers and the market, causing mis-valuation to be unavoidable, which was reflected in the FV that was greater than the fundamental value (overvalue). In other words, the managers only instilled growth illusion in the mind of the market with the purpose of maintaining the FV condition (which was overvalued). It is evident that the motivation of the managers in creating this illusion is related to bonuses for firm performance (Healy, 1985; Jensen, 2005).

A differing finding occurred in AM practice, which was unable to draw the market's response. Zang (2012)found that managers face a stumbling block in practicing AM when the supervision of auditors and regulators is strict. This evidence indicated that the market highly trusted auditor credibility in the manufacturing sector on the IDX. Although managers created value through AM, the market had found out about the illusion and mispricing on the equity can be avoided.

Identical evidence was found in the relationship between RMD and FV. This finding showed that there was no significant relationship between RMD and FV. 
Managers technically practiced RMD by delaying the research and development, advertising and maintenance expenses. As a consequence, the firm sacrificed value by postponing a project. The market knew that the delay of a new project would lower future earnings performance instead.

Moreover, the three control variables involved in the model showed that ROA and SIZE had a significant, negative relationship with FV. This evidence came as a surprise as the market tends to be attracted to a firm with the small total asset (SIZE) and ROA. This proved that the FV increase is not accompanied by the strong firm fundamentals (ROA and SIZE). On the other side, the equity performance shown through ROE did not affect the market decision in triggering the increase of FV. This evidence can be understood to be similar to the findings by Nissim (2013), who stated that ROE can only increase the accuracy in book value assessment.

Overall, this research findings showed that earnings management through RMP method had been proven to be able to encourage firm value increase. This research results support the overvaluation of equity hypothesis (Jensen, 2005) that earnings management is considered as an integral part of the top management job and can jack up firm value. Also, these results are also consistent with the findings of Bruns \& Merchant (1990) and Graham et al., (2005), who stated that managers are more often than not involved in RM practice in earnings management. This research supports the findings of Roychowdhury (2006) that managers insist on practicing RMP although the consequence of this action may harm the cash flow as it causes oversupply, which will put expense burden to the firm.

\subsection{Additional Analysis (Sensitivity Test)}

Daske and Gebhardt (2006) announced that IFRS adoption might minimize the likelihood of manager opportunism and earnings management as IFRS can reduce the scope of manager discretion. However, there has been much evidence of the relationship between IFRS and earnings management. Iatridis and Rouvolis (2010) did not find weakened earnings management after the adoption of IFRS in Greek companies. Similarly, Callao and Jarne (2010), who used samples from 11 European 
Union countries in the period 2003-2006 provided evidence that there was an increase in the discretionary accrual (AM) after IFRS adoption.

Contrasting results were shown by Chen et al. (2010), who found that discretionary accrual (AM) as a proxy of earnings management declined after IFRS adoption in 15 European Union countries. Similar findings were shown by Zéghal, Chtourou, and Sellami (2011), who proved that IFRS adoption in a mandatory could minimize earning management in firms in France. The researcher interpreted these findings as evidence that IFRS application has differing impacts on different countries.

Furthermore, previous studies demonstrated that the big 4 auditors restricted earnings management through AM (Becker, DeFond, Jiambalvo, \& Subramanyam, 1998; DeFond \& Jiambalvo, 1991; Defond \& Jiambalvo, 1993; Francis, Maydew, \& Sparks, 1999). Big 4 auditors are considered to have higher auditing quality as they tend to be more experienced by investing mainly in resources in the auditing sector, and they have a better reputation for risk than smaller auditing firms. Managers found it harder to convince auditors of higher quality about their aggressive accounting practice than to persuade auditors of lower quality (Zang, 2012).

Also, Roychowdhury (2006) showed that the higher the institutional investors' ownership, the lower the RM. This indicated that managers would have less flexibility in practicing $\mathrm{RM}$ when the institutional ownership in a firm is relatively high. Likewise, Zang (2012) stated that institutional investors are more sophisticated and have better information than other investors, making them more informed about the long-term implications of monitoring firm operational decisions. Therefore, managers will face a stumbling block in practicing RM when institutional investors monitor their operational activities. Bushee (1998) presented evidence that when there is higher institutional ownership in a firm, the firm will tend to reduce $R \& D$ expenses to avoid decreased earnings.

The results of the dummy variable testing as a chow test alternative (see table 6) showed that the impacts of AM, RMP, and RMD on FV were different when the firms were audited by auditors affiliated with the big 4 , when the institutional ownership was high and pra and post IFRS adoption. These differences could be caused by the 
differences in the quality of audit, institutional investor supervision, transparency and accounting numbers after the adoption of IFRS.

Table 6

Sensitivity Test

\begin{tabular}{|c|c|c|c|}
\hline Differential & $\begin{array}{c}\text { Model 1 } \\
\mathrm{AM} \rightarrow \mathrm{FV}\end{array}$ & $\begin{array}{c}\text { Model } 2 \\
\text { RMP } \rightarrow \text { FV }\end{array}$ & $\begin{array}{c}\text { Model 3 } \\
\text { RMD } \rightarrow \text { FV }\end{array}$ \\
\hline \multicolumn{4}{|c|}{ Panel A: Big 4 auditor affiliatedand non affiliated } \\
\hline Differential Intercept $\left(\alpha_{2}\right)$ & $0.019 * * *$ & $0.013 * * *$ & $0.016 * * *$ \\
\hline Differential Slope Coefficient $\left(\beta_{2}\right)$ & -0.031 & $0.070 * * *$ & $-0.082 * * *$ \\
\hline Conclusions & Paralel regression & $\begin{array}{l}\text { Dissimilar } \\
\text { regression }\end{array}$ & $\begin{array}{l}\text { Dissimilar } \\
\text { regression }\end{array}$ \\
\hline \multicolumn{4}{|c|}{ Panel B: Institutional investorsand non institutional investors } \\
\hline Differential Intercept $\left(\alpha_{2}\right)$ & $-0.012 * * *$ & -0.005 & $-0.006^{*}$ \\
\hline Differential Slope Coefficient $\left(\beta_{2}\right)$ & 0.035 & $-0.090 * * *$ & 0.035 \\
\hline Conclusions & Paralel regression & $\begin{array}{l}\text { Concurrent } \\
\text { regression }\end{array}$ & Paralel regression \\
\hline \multicolumn{4}{|l|}{ Panel C: Praandpost IFRS adoption } \\
\hline Differential Intercept $\left(\alpha_{2}\right)$ & $0.040 * * *$ & $0.041 * * *$ & $0.041 * * *$ \\
\hline Differential Slope Coefficient $\left(\beta_{2}\right)$ & $0.052 * * *$ & $0.025 *$ & $0.033 *$ \\
\hline Conclusions & $\begin{array}{l}\text { Dissimilar } \\
\text { regression }\end{array}$ & $\begin{array}{l}\text { Dissimilar } \\
\text { regression }\end{array}$ & $\begin{array}{l}\text { Dissimilar } \\
\text { regression }\end{array}$ \\
\hline
\end{tabular}

\section{Conclusions, Implications, and Limitations of Research}

\subsection{Conclusion}

This study has presented an empirical investigation with a sample consisting of manufacturing companies listed on the IDX and proved that managers practiced earnings management to increase firm value in the period 2010-2014. The observed earnings management was proxied with AM and RM. AM was estimated using the Modified Jones Model (1991) that was developed by Dechow, Sloan, \& Sweeney (1995). Meanwhile, RM was estimated using abnormal production cost (RMP) and abnormal discretionary expenses (RMD) - models developed by Roychowdhury 
(2006). Afterward, firm value (FV) was estimated using the measure built by (RhodesKropf et al., 2005).

This research contributes to the literature concerning earnings management by showing that the increase in the value creation practice through earnings management plays a role in FV increase. First, the results presented empirical evidence that FV increases as a result of the RMP increase. The results of the additional analysis showed that the relationship between RMP and FV is different when the firm is audited by auditors affiliated with the big4, when an institutional investor is present and when IFRS is adopted. Second, the results showed no evidence of the relationship between $\mathrm{AM}$ as well as RMD and FV. This finding indicated that the managers practicing AM or RMD do not influence market response, thus unable to move FV. However, based on the sensitivity test results, the relationships between AM, RMD, and FV are different when restricted by an auditor affiliated with the big 4 auditors, when an institutional investor is present and when IFRS is adopted.

\subsection{Implications}

The empirical findings showing that RMP practice can encourage FV have an implication for researchers, regulators and analysts/investors. For researchers, this relationship indicates that the focus solely on AM or RM will not holistically explain earnings management activities. As for regulators, increased supervision will not entirely root out earnings management as managers still can create growth illusion through RMP. These results serve as a useful information supplement for analysts or investors in evaluating the quality of financial statements of manufacturing companies listed on the IDX. For example, these results may be helpful for decision making relating to share selection and credit decisions.

\subsection{Research Limitations and Future Research Agenda}

One of the limitations of this research is that this model is sensitive to differing audit quality, the presence of an institutional investor and IFRS adoption. However, this research only estimated the difference occurrence, rather than the relationship 
pattern, in those varied conditions. Thus, it is expected that these findings become a guideline that needs to be explored for future research.

\section{References}

Ameer, R. (2012). Impact of Cash Holdings and Ownership Concentration on Firm Valuation Empirical Evidence from Australia. Review of Accounting and Finance, 11(4), 448-7702. doi:10.1108/14757701211279196

Badertscher, B. A. (2011). Overvaluation and the Choice of Alternative Earnings Management Mechanisms. The Accounting Review, 86(5), 1491-1518. doi:10.2308/accr-10092

Barton, J., \& Simko, P. J. (2002). The Balance Sheet as an Earnings. The Accounting Review, 77(Supplement), 1-27.

Barton, J., \& Waymire, G. (2004). Investor Protection Under Unregulated Financial Reporting. Journal of Accounting and Economics, 38(1-3 SPEC. ISS.), 65-116.

Becker, C. L., DeFond, M. L., Jiambalvo, J., \& Subramanyam, K. R. (1998). The effect of audit quality on earnings management. Contemporary Accounting Research, 15(1), 1-24.

Braam, G., Nandy, M., Weitzel, U., \& Lodh, S. (2013). Accrual-based and real earnings management and political connections. International Journal of Accounting, (2015). doi:10.1016/j.intacc.2013.10.009

Bruns, W., \& Merchant, K. (1990). The Dangerous Morality of Managing Earnings. Management Accounting, 72(2), pg. 22.

Bushee, B. J. (1998). The Influence of Institutional Investors on Myopic R\&D Investment Behavior. The Accounting Review, 73(3), 305-333.

Callao, S., \& Jarne, J. I. (2010). Have IFRS Affected Earnings Management in the European Union? Accounting in Europe, 7(Dec 2010), 159-189. doi:10.1080/17449480.2010.511896

Chaney, P. K., \& Lewis, C. M. (1995). Earnings Management and Firm Valuation Under Asymmetric Information. Journal of Corporate Finance, 1, 319-345.

Chaney, P. K., \& Lewis, C. M. (1995). Earnings Management and Firm Valuation under Asymmetric Information. Journal of Corporate Finance, 1, 319-345.

Chen, H., Tang, Q., Jiang, Y., \& Lin, Z. (2010). The Role of International Financial Reporting Standards in Accounting Quality: Evidence from the European Union. Journal of International Financial Management and Accounting, 21(3), 220-278.

Chi, J., \& Gupta, M. (2009). Overvaluation and Earnings Management. Journal of Banking and Finance, 33(9), 1652-1663. doi:10.1016/j.jbankfin.2009.03.014 
Cohen, D. A., \& Zarowin, P. (2010). Accrual-based and Real Earnings Management Activities Around Seasoned Equity Offerings. Journal of Accounting and Economics, 50(1), 2-19. doi:10.1016/j.jacceco.2010.01.002

Daske, H., \& Gebhardt, G. (2006). International Financial Reporting Standards and Experts ' Perceptions of Disclosure Quality. Abacus, 42(3/4), 461-498. doi:10.1111/j.14676281.2006.00211.x

Davydov, D., Nikkinen, J., \& Vähämaa, S. (2014). Does the Decision to Issue Public Debt Affect Firm Valuation? Russian Evidence. Emerging Markets Review, 20, 136-151. doi:10.1016/j.ememar.2014.06.004

Dechow, P. M., Hutton, A. P., \& Sloan, R. G. (2000). The Relation between Analysts' Forecasts of Long-Term Earnings Growth and Stock Price Performance Following Equity Offerings. Contemporary Accounting Research, 17(1), 1-32.

Dechow, P. M., Kothari, S. P., \& Watts, R. L. (1998). The Relation Between Earnings and Cash Flows. Journal of Accounting and Economics, 25(2), 133-168.

Dechow, P. M., Sloan, R. G., \& Sweeney, A. P. (1995). Detecting Earnings Management. The Accounting Review, 70(2), 193-225. Retrieved from

http://www.jstor.org/stable/248303 \nhttp://www.jstor.org/stable/pdfplus/248303.pdf?acce ptTC=true

DeFond, M. L., \& Jiambalvo, J. (1991). Incidence and Circumstances of Accounting Errors. The Accounting Review, 3(66), 643-655. Retrieved from http://www.jstor.org/stable/247814

Defond, M. L., \& Jiambalvo, J. (1993). Factors Related to Auditor-Client Disagreements over Income-Increasing Accounting Methods. Contemporary Accounting Research, 9(2), 415431. Retrieved from

http://search.ebscohost.com/login.aspx?direct=true \&db=bth\&AN=10966332\&site=ehost$\underline{\text { live } \& \text { scope }=\text { site }}$

Doyle, J. T., Ge, W., \& Mc Vay, S. (2007). Accrual Quality and Internal Control over Financial Reporting. The Accounting Review, 82(5), 1141-1170.

Efendi, J., Srivastava, A., \& Swanson, E. P. (2007). Why Do Corporate Managers Misstate Financial Statements? The Role of Option Compensation and Other Factors. Journal of Financial Economics, 85, 667-708. doi:10.1016/j.jfineco.2006.05.009

Francis, J. R., Maydew, E. L., \& Sparks, H. C. (1999). The Role of Big 6 Auditors in the Credible Reporting of Accruals. Auditing: A Journal of Practice \& Theory, 18(2), 17-34.

Fu, F., Lin, L., \& Officer, M. S. (2013). Acquisitions Driven by Stock Overvaluation : Are They Good Deals? Journal of Financial Economics, 109(1), 24-39. doi:10.1016/j.jfineco.2013.02.013 
Gaio, C., \& Raposo, C. (2011). Earnings quality and firm valuation : international evidence *. Accounting and Finance, 51(March 2010), 467-499.

Graham, J. R., Harvey, C. R., \& Rajgopal, S. (2005). The Economic Implications of Corporate Financial Reporting. Journal of Accounting and Economics, 40(1-3), 3-73. doi:10.1016/j.jacceco.2005.01.002

Gujarati. (2004). Basic Econometrics (Fourth Edi., p. 1002). The McGraw-Hill Companies.

Gunny, K. (2010). The Relation Between Earnings Management Using Real Activities Manipulation and Future Performance: Evidence from Meeting Earnings Benchmarks. Contemporary Accounting Research, 27(3), 855-888. doi:10.1111/j.19113846.2010.01029.x

Healy, P. M. (1985). The Effect of Bonus Schemes on Accounting Decisions. Journal of Accounting and Economics, 7, 85-107.

Houmes, R., Foley, M., \& Cebula, R. J. (2013). Audit Quality and Overvalued Equity. Accounting Research Journal, 26(1), 56-74. doi:10.1108/ARJ-08-2011-0024

Iatridis, G., \& Rouvolis, S. (2010). The Post-Adoption Effects of the Implementation of International Financial Reporting Standards in Greece. Journal of International Accounting Auditing and Taxation, 19(1), 55-65. doi:10.1016/j.intaccaudtax.2009.12.004

Jensen, M. (2005). Costs of Overvalued Equity. Financial Management, 34(1), 5-19.

Jensen, M. C., \& Meckling, W. H. (1976). Theory of The Firm: Managerial Behavior, Agency Cost, and Ownership Structure. Journal of Financial Economics, 3(4), 305-360.

Kothari, S. P., Mizik, N., \& Roychowdhury, S. (2012). Managing for the Moment: The Role of Real Activity Versus Accruals Earnings Management in SEO Valuation. Working Paper. Retrieved from http://papers.ssrn.com/sol3/papers.cfm?abstract_id=1982826

Lin, H., Chou, T., \& Cheng, J. (2011). Does Market Misvaluation Drive Post-acquisition Underperformance in Stock Deals? International Review of Economics and Finance, 20(4), 690-706. doi:10.1016/j.iref.2010.12.005

Marciukaityte, D., \& Varma, R. (2008). Consequences of Overvalued Equity: Evidence from Earnings Manipulation. Journal of Corporate Finance, 14, 418-430. doi:10.1016/j.jcorp

Nissim, D. (2013). Relative Valuation of U.S. Insurance Companies. Review Accounting Study, 18(October 2012), 324-359. doi:10.1007/s11142-012-9213-8

Rhodes-Kropf, M., Robinson, D. T., \& Viswanathan, S. (2005). Valuation Waves and Merger Activity: The Empirical Evidence. Journal of Financial Economics, 77, 561-603. doi:10.1016/j.jfineco.2004.06.015 
Roychowdhury, S. (2006). Earnings Management Through Real Activities Manipulation. Journal of Accounting and Economics, 42(3), 335-370. doi:10.1016/j.jacceco.2006.01.002

Siougle, G. (2007). Accounting Information and The Valuation of Seasoned Equity Offerings ( SEOs ). The International Journal of Accounting, 42, 380-395. doi:10.1016/j.intacc.2007.09.005

Teoh, S. H., Welch, I., \& Wong, T. J. (1998). Earnings Management and the Underperformance of Seasoned Equity Offerings. Journal of Financial Economics, 50(October 1995), 63-99.

Watts, R. L., \& Zimmerman, J. L. (1990). Positive Accounting Theory: A Ten Year Perspective. The Accounting Review, 65(1), 131-156.

Zang, A. Y. (2012). Evidence on the Trade-Off between Real Activities Manipulation and Accrual-Based Earnings Management. The Accounting Review, 87(2), 675-703. doi:10.2308/accr-10196

Zéghal, D., Chtourou, S., \& Sellami, Y. M. (2011). An Analysis of the Effect of Mandatory Adoption of IAS / IFRS on Earnings Management. Journal of International Accounting Auditing and Taxation, 20, 61-72. doi:10.1016/j.intaccaudtax.2011.06.001 